\title{
Impacts of land use and topography on soil organic carbon in a Mediterranean landscape (north-western Tunisia)
}

\author{
Donia Jendoubi $^{1,2}$, Hanspeter Liniger ${ }^{1}$, and Chinwe Ifejika Speranza ${ }^{2}$ \\ ${ }^{1}$ Centre for Development and Environment (CDE), University of Bern, Bern, 3012, Switzerland \\ ${ }^{2}$ Institute of Geography, University of Bern, Bern, 3012, Switzerland \\ Correspondence: Donia Jendoubi (donia.jendoubi@cde.unibe.ch)
}

Received: 21 March 2019 - Discussion started: 8 April 2019

Revised: 30 July 2019 - Accepted: 13 August 2019 - Published: 2 September 2019

\begin{abstract}
This study evaluates the impact of land use and topographic features (slope and aspect) on soil organic carbon (SOC) within the Wadi Beja watershed in north-western Tunisia. A soil spectral library was set up to assess the variation in the SOC for 1440 soil samples from four land use types (field crops, permanent crops, forest, and grazing land), three slope categories (flat, moderate, and steep) and two aspects (north- and southfacing). For field crops, only one factor - slope - significantly affected SOC, with SOC content in north-facing areas appearing to be higher in flat areas $(0.75 \%)$ than in hilly areas $(0.51 \%)$. However, in south-facing areas, SOC content was also higher in flat areas $(0.74 \%)$ than in hilly areas $(0.50 \%)$. For permanent crops, which were inter-planted with field crops, the slope significantly affected SOC content, which improved to $0.97 \%$ in flat north-facing and $0.96 \%$ in flat south-facing areas, scoring higher than hilly south- and north-facing areas $(0.79 \%)$. In the grazing land use system, both of the investigated factors - aspect and slope - significantly affected the SOC content, which was significantly higher in flat areas (north-facing: $0.84 \%$, south-facing: $0.77 \%$ ) than in hilly areas (north-facing: $0.61 \%$, south-facing: $0.56 \%$ ). For the forest, none of the factors had a significant effect on SOC content, which was higher in flat areas (north-facing: $1.15 \%$, south-facing: $1.14 \%$ ) than in steep areas $(1.09 \%$ in north-facing areas and $1.07 \%$ in south-facing areas). This study highlights the ability of visible and near-infrared (VNIR) spectroscopy to quantify $\mathrm{C}$ in diverse soils collected over a large diverse geographic area in order to indicate that calibrations are feasible, and therefore, assessing the variation of SOC content under land use and topographic features (slope and aspect) will result in better sustainable land management planning.
\end{abstract}

1

\section{Introduction}

Land degradation is a major challenge for Mediterranean arid and semi-arid ecosystems (Hill et al., 2008). In Tunisia, human activities are responsible for land degradation through deforestation, overgrazing, removal of natural vegetation, and agricultural practices that exacerbate soil erosion (Sarraf et al., 2004). Long-term anthropogenic pressure from agricultural use (Kosmas et al., 2015) together with abiotic factors such as climatic and topographical variability (Scarascia-Mugnozza et al., 2000) create diverse situations for which it is difficult to draw generally valid assump- tions concerning SOC distribution and its determinant factors (Jobbagy and Jackson, 2000).

Furthermore, soil quality degradation contributes to the deterioration of other land resources (e.g. water and vegetation) (Karamesouti et al., 2015). Soil degradation processes include biological degradation (e.g. soil fertility and soil fauna decline), physical degradation (e.g. compaction, soil erosion, and waterlogging), and chemical degradation (e.g. acidification nutrient and depletion), which are mostly caused by agricultural practices (Diodato and Ceccarelli, 2004; Post and Kwon, 2000). There are both natural and human-induced causes of soil degradation (Bhattacharyya et al., 2015). 
The soil quality concept has been proposed for application in studies on sustainable land management (Doran, 2002). When using the term "soil quality", it must be linked to a specific function. In this study, soil quality is seen in relation to soil conservation in agricultural systems, which aim to maintain the capacity of soil to function as a vital living system for sustaining biological productivity, promoting environmental quality and maintaining plant and animal health (Doran and Zeiss, 2000).

To measure soil quality, minimum datasets have been suggested that allow a detailed description through the inclusion of soil chemical and physical indicators (Lal, 1998). However, integrative indicators are more appropriate for preliminary studies, as they efficiently provide insights into general soil quality. Soil organic matter (OM) is one such integrative measure of soil quality, influencing soil stability, soil fertility, and hydrological soil properties. OM plays a crucial role in soil erosion: when the erosion removes surface soil, the OM and clay vanish, resulting in a decline in soil fertility and biological activity, and in soil aggregation (Wolfgramm et al., 2007). In soils with high calcareous silty amounts and in the absence of clay, OM is particularly important with regard to the soil's physical properties (e.g. soil structure, porosity, and bulk density), which again determine erodibility (Hill and Schütt, 2000).

Mediterranean soils are characterized by low amounts of OM, which results in soil fertility decline and structure loss (Van-Camp et al., 2004). Furthermore, SOC is variable across land use (Brahim et al., 2010), and most agricultural soils are poor in OM, often comprising less than $1 \%$ (Achiba et al., 2009; Parras-Alcántara et al., 2016; Muñoz-Rojas et al., 2012). In Mediterranean soils, loss of OM leads to a reduction in root penetration, soil moisture, and soil permeability, which in turn reduces vegetation cover and biological activity and increases runoff and risk of erosion (Stanners and Bourdeau, 1995).

Tunisia has one of the highest SOC depletion rates among Mediterranean countries (Brahim et al., 2010). Its low soil fertility is considered a sign that inappropriate land management systems are predominant in the country (Hassine et al., 2008; Achiba et al., 2009). In north-western Tunisia, soils are mostly derived from an alteration of carbonate sedimentary parent material (marl, limestone, clay), cultivated under rainfed conditions to produce cereal crops (wheat and barley) (Hassine et al., 2008). This form of cultivation decelerates the mineralization of OM through a series of unsustainable practices, including deep ploughing in spring and summer, stubble ploughing in autumn to protect wheat from Fusarium, and various tillage operations preceding sowing (Hassine et al., 2008). This relatively intensive soil cultivation, accompanied by the practice of an annual application of phosphate and nitrogen fertilizers, is at the root of the decrease in OM content following stimulation of microbial activity (ÁlvaroFuentes et al., 2008).
Understanding the above dynamics and SOC distribution as influenced by land use systems and topographic features is critical for assessing land use management planning (Kosmas et al., 2000). SOC contents are influenced by topographic features and climate variation, specifically temperature and water (García Ruiz et al., 2012).

Currently, the north-western region of Tunisia is enduring extensive field crop monoculture and land degradation owing to population increase, inappropriate land management, and rough topographic features. Much of the cropped land is unsuitable for agriculture and degrades quickly. The impacts of agricultural practices and topography on nutrient cycling and ecological health, however, have not been studied extensively in the Tunisian north-western region.

Due to this dispute, SOC contents measured over time can establish the long-term productivity and possible sustainability of a land use system. In a nutrient-poor system, SOC can play an important role in the stability, quality, and fertility of the soil. Farmers and land use planners are therefore interested in land use management that will enhance soil carbon content.

The aim of this study is to quantify SOC content and evaluate the factors that affect SOC variation, specifically the mechanisms affecting differences in SOC distribution patterns along different land use systems and topographic features (slope and aspect) in a Mediterranean ecosystem dominated by agricultural activities in north-western Tunisia.

Information on soil quality is crucial for improving decision-making around efficient support of sustainable land management. Thus, methods are needed for fast and inexpensive prediction of important soil quality indicators such as SOC. The potential of diffuse reflectance spectroscopy in the visible and near-infrared (VNIR) range for fast prediction of soil properties in a non-destructive and efficient way has been demonstrated by a number of studies (Amare et al., 2013; Shiferaw and Hergarten, 2014; Shepherd and Walsh, 2002).

We are not aware of any study evaluating the impacts of topographic features (slope and aspect) or existing land use systems on SOC dynamics in Mediterranean agricultural soils, specifically in Tunisia, based on an accurate and consistent database such as a soil spectral library.

Most soils in north-western Tunisia are exposed to water erosion, which is provoked by poor cover, cultivation practices, and hilly topography. The Wadi Beja watershed was selected because it comprises a variety of degraded areas and areas where soil and water conservation practices (SWC) are applied. It is the most productive and extended cereal area in Tunisia and faces serious risks associated with monoculture production of field crops under inappropriate land management practices. Some new practices, such as agroforestry, were introduced into the region in the 1980 s, along with permanent crops such as olive and almond trees.

The first research objective was to build a soil spectral library in order to apply it to the Wadi Beja watershed, as there 


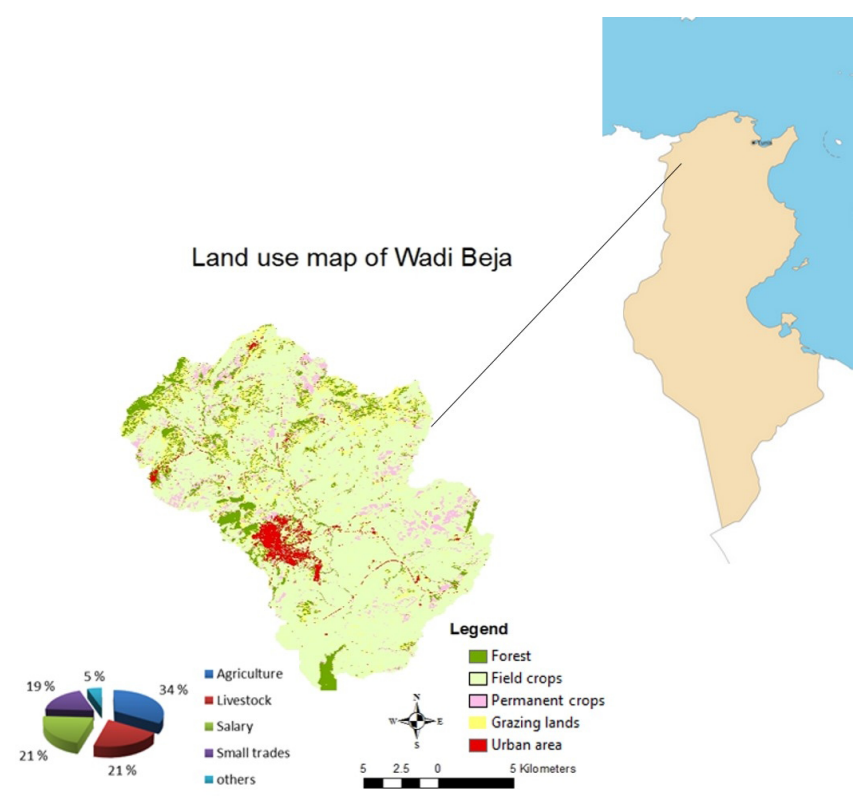

Figure 1. Characterization of household income, location, and land uses of the study area, Wadi Beja watershed, north-western Tunisia. Source: Jendoubi et al. (2019).

was no accurate or valid soil database for the studied region or even for the whole country. The second objective was to examine the distribution of SOC under the different slopes, aspects, and land use systems. The third objective was to investigate, specifically, two hypotheses. (1) Land management practices under different abiotic factors (e.g. topography) influence soil SOC variation. (2) Ecosystems are more sensitive to soil degradation (SOC loss) on steep and south-facing slopes than on gentle and north-facing slopes.

\section{Materials and methods}

\subsection{Study area}

The study area, the Wadi Beja watershed, lies at $36^{\circ} 37^{\prime} 60^{\prime \prime} \mathrm{N}$ and $9^{\circ} 13^{\prime} 60^{\prime \prime} \mathrm{E}$ in north-western Tunisia. Upstream of Wadi Beja is the Amdoun region and downstream the junction with Wadi Medjerdah in the Mastutah region. Wadi Beja is a tributary of the Wadi Majerdah, the most prominent river in Tunisia (Fig. 1).

The watershed (about $338 \mathrm{~km}^{2}$ ) covers diverse topographic features, with an elevation ranging from 110 to nearly $750 \mathrm{~m}$ a.s.l.; slopes range from flat $(0 \%-8 \%)$ to moderate $(8 \%-16 \%)$ and steep $(>16 \%)$ areas, with $64 \%$ having a steep slope and $36 \%$ a moderate slope. Annual rainfall is irregular and varies from 200 to $800 \mathrm{~mm}$. Early October to the end of April (late autumn to early spring) is considered the rainy season (AVFA, 2016). During the summer it is very dry and hot. The maximum temperatures are recorded at the end of July and range from 38 to $44^{\circ} \mathrm{C}$. Minimum temperatures are recorded at the end of December and fall between 6 and $8^{\circ} \mathrm{C}$ (AVFA, 2016). In the Beja region, the population is mainly rural ( $56 \%$ ), with $48.5 \%$ being active in the agricultural sector. Agriculture remains the main source of household income (55\%, including livestock) (Fig. 1). Nearly $78 \%$ of rural households live entirely off their farms (AVFA, 2016). There are three types of farming systems: extensive $(83 \%)$, intensive $(6 \%)$, and mixed $(11 \%)$. Five different land use systems (LUS) have been defined: field crops $(71 \%)$, grazing lands $(10 \%)$, forest $(9 \%)$, permanent crops (7\%), and built-up areas (3\%).

The current soil types in the study area are vertisols, which cover $46 \%$ of the total area, isohumic soils (23\%), brown calcareous soils (12\%), and regosols (10\%). Rendzinas soils, lithosoils, hydromorphic soils, and fersiallitic soils also exist, covering small areas that add up to less than $9 \%$ according to the agricultural map of Tunisia.

Land management in the study area is similar in relation to land preparation, organic amendments, crop rotation, and mulching (stubble, roots). Mineral fertilizers have been applied for several decades, and cropland - the most common land use - has been used for monoculture of cereal crops such as wheat and barley.

\subsection{Methods}

\subsubsection{Land use change history}

A land use system (LUS) is defined as a sequence of goods and services obtained from land, but can involve particular management interventions undertaken by the land users as well. It is generally determined by socio-economic market forces as well as the biophysical constraints and potentials imposed by the ecosystems in which they occur (Nachtergaele et al., 2010).

This study investigated four land use systems - field crops, permanent crops, forest plantation, and grazing land - in order to assess their effects on the variation of SOC (Table 1). Built-up areas and roads were excluded. We used atmospherically corrected Landsat Surface Reflectance data images (bands 4-5, 7, and 8) from 1985, 2002, and 2016 to derive the land use maps in order to evaluate the changes over that time period (Jendoubi et al., 2019).

The Landsat scenes were selected from among all those available in the green season (out of harvesting) for the corresponding years; we considered only those with less than $20 \%$ of cloud cover overall and without clouds in the study site area. Unsupervised classification was carried out for the images in order to define the major land use systems. Following this, a validation based on ground truth data was made in order to confirm the generated land use maps and assess their accuracies.

Table 1 illustrates substantial land use and land cover change (LULC) in the Wadi Beja watershed after 1980. 
Table 1. The five major land use and management classes studied in the Wadi Beja watershed, Tunisia.

\begin{tabular}{lrr|rr|rr}
\hline \multirow{2}{*}{$\begin{array}{l}\text { Aggregated land } \\
\text { use classes }\end{array}$} & \multicolumn{2}{c|}{1985} & \multicolumn{2}{|c|}{2002} & \multicolumn{2}{|c}{2016} \\
\cline { 2 - 7 } & $\%$ & $\mathrm{~km}^{2}$ & $\%$ & $\mathrm{~km}^{2}$ & $\%$ & $\mathrm{~km}^{2}$ \\
\hline Field crops & 82.1 & 272.7 & 76.4 & 254.0 & 71.0 & 236.2 \\
Grazing lands & 9.3 & 30.9 & 10.2 & 33.7 & 9.7 & 32.2 \\
Forests & 3.9 & 13.1 & 7.7 & 25.6 & 8.9 & 29.6 \\
Permanent crops & 3.4 & 11.2 & 4.2 & 14.1 & 7.3 & 24.4 \\
Built-up areas & 1.3 & 4.5 & 1.5 & 4.9 & 3.1 & 10.0 \\
\hline Total & 100 & 332.4 & 100 & 332.4 & 100 & 332.4 \\
\hline
\end{tabular}

Source: Jendoubi et al. (2019).

Field crops constituted the predominant land use type, accounting for approximately $82 \%$ in 1985 and $71 \%$ in 2016 . Plantation forest also increased from $3.9 \%$ in 1985 to $9 \%$ of the watershed in 2016. In 1980, to remedy the degrading effects of monoculture of annual cropping, deforestation, and overgrazing on pastures and forests, a programme developed by ODESYPANO (Office Development Sylvo-Pastoral Nord Ouest) and financed by the World Bank implemented some conservation activities, including development of permanent vegetative cover using olive trees and sylvo-pastoral management. An agroforestry (agro-sylvo-pastoral) system was introduced in 1982 as an alternative programme for development and conservation in the region. This system included converting annual cropping into a combination of annual crops inter-planted with olive trees (in this study classified as "permanent crops"). This area increased from $3.4 \%$ in 1985, when it was introduced for the first time in the region, to $7.3 \%$ in 2016 . The local farmers took this alternative as they believed that their soils had become poor and no longer gainful for annual crop production. Grazing land remained almost unchanged in terms of area, as it is spread over badlands, barren lands, and riverbanks with a high concentration of eroded and poor soils.

\subsubsection{Soil sampling}

We selected four land use systems (LUS) (excluding built-up areas), three slope classes, and two aspect classes to study their interrelations and their effects on SOC. The LUS were forests, field crops, permanent crops, and grazing land (Table 1). Aspect and slope units were derived from lidar DTM, aligned, and resampled to $30 \mathrm{~m}$. Slope categorization was based on the FAO soil description guidelines (Barham et al., 1997). The slope categories were grouped into three classes: flat, moderate, and steep. Aspect was categorized into two classes: north and south. Details of slope and aspect categories are presented in Table 2.

From all slope and aspect classes and different land use systems (LUS), soil samples were collected randomly from the topsoil $(0-20 \mathrm{~cm})$. In a factorial randomized design con-
Table 2. Slope and aspect.

\begin{tabular}{ll}
\hline Slope (\%) & Aspect (azimuth degrees) \\
\hline 0 to 8 (Flat) & 0 to 90,270 to 360 (North) \\
8 to 16 (Moderate) & 90 to 270 (South) \\
$>16$ (Steep) & \\
\hline
\end{tabular}

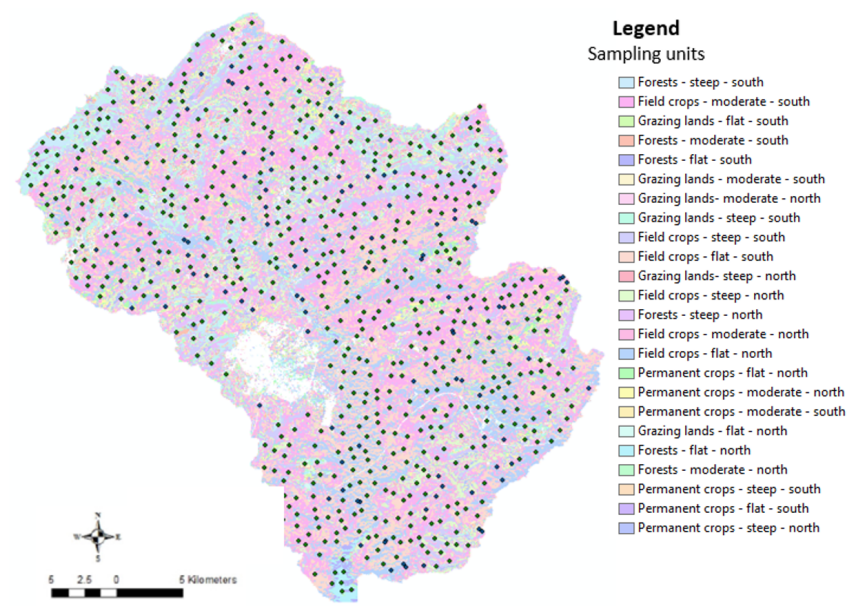

Figure 2. Location of the soil samples and the sampling design.

sidering the four land use types, three slopes, and two aspects, a total of 24 different sampling units $(n=4 \times 3 \times 2)$ were considered. In total, 1440 soil samples were collected from all the sampling units in the topsoil layer $(0-20 \mathrm{~cm})$ using a soil auger ( $10 \mathrm{~cm}$ diameter) with an average of 60 samples per sampling unit.

The sampling design shown in Fig. 2 summarizes the strategy of the sampling. Sampling units are listed as shown in Table 3.

\subsubsection{Soil analysis and spectral library}

The soil spectral library was set according to protocols cited by Shepherd and Walsh (2002), and includes the following steps: (1) representative sampling of soil variability in the study area; (2) establishing the soil reflectance spectral dataset using VNIR spectrometry; (3) selecting a reference dataset to be analysed using traditional soil chemical methods required as reference values ( 450 samples, or $31 \%$ of the total, were selected according to their spectral variability); (4) determination of SOC by means of soil chemical analysis (CNS elemental analysis); (5) calibrating soil property data to soil reflectance spectra by applying multivariate calibration models; and finally (6) prediction of new samples using the spectral library.

The soil spectral library for prediction of SOC was adjusted using a mug light for illumination as described by $\mathrm{Mu}-$ tuo et al. (2006). Soil spectral reflectance was measured under standard conditions in the laboratory. Soil samples were 
Table 3. Sampling units with their corresponding number of soil samples.

\begin{tabular}{lr}
\hline Sampling units & Number of soil samples \\
\hline Field crops - flat - north & 65 \\
Field crops - flat - south & 66 \\
Field crops - moderate - north & 60 \\
Field crops - moderate - south & 62 \\
Field crops - steep - north & 57 \\
Field crops - steep - south & 59 \\
Permanent crops - flat - north & 60 \\
Permanent crops - flat - south & 62 \\
Permanent crops - moderate - north & 55 \\
Permanent crops - moderate - south & 57 \\
Permanent crops - steep - north & 63 \\
Permanent crops - steep - south & 65 \\
Forests - flat - north & 60 \\
Forests - flat - south & 54 \\
Forests- moderate - north & 57 \\
Forests - moderate - south & 60 \\
Forests - steep - north & 61 \\
Forests - steep - south & 59 \\
Grazing lands - flat - north & 60 \\
Grazing lands - flat - south & 63 \\
Grazing lands- moderate - north & 55 \\
Grazing lands - moderate - south & 59 \\
Grazing lands- steep - north & 62 \\
Grazing lands - steep - south & 59 \\
\hline
\end{tabular}

air dried (to $30^{\circ} \mathrm{C}$ ) and sieved to pass through a $2 \mathrm{~mm}$ mesh. Soil samples of $2 \mathrm{~mm}$ thickness were placed into borosilicate Duran glass Petri dishes with optimal optical characteristics. The Petri dishes were placed on a mug light equipped with a Tungsten Quartz Halogen light source (Analytical Spectral Devices, Boulder, CO). Spectral reflectance readings were collected through the bottom of the Petri dishes using a FieldSpec PRO FR spectro-radiometer (Analytical Spectral Devices, Boulder, $\mathrm{CO}$ ). Every sample was measured twice, with the sample rotated by $90^{\circ}$ for the second measurement. The two measurements were averaged, which minimized light scatter effects from uneven particle size distribution on the Petri dish floor. The instrument works with three spectroradiometers to cover the wavelengths from 350 to $2500 \mathrm{~nm}$ at an interval of $1 \mathrm{~nm}$. The fore-optic view was set to $8^{\circ}$. For dark current readings, 25 scans were averaged, while for white reference and soil spectral readings 10 scans were averaged by the spectro-radiometer. Before each sample reading, white reference readings were taken from a spectralon (Labsphere) that was placed on a trimmed Petri dish bottom.

Pre-processing of soil reflectance data to decrease the noise present in the data and thus increase robustness of reflectance spectral data is common in VNIR spectrometry and is especially important in the case of measuring setups that are difficult to control (e.g. due to power fluctuations or different operators during different measuring sessions).
The main pre-processing steps conducted were as follows: spectra were compressed by selection of every 10th nanometre. Spectral bands in the lowest $(350-430 \mathrm{~nm})$ and highest $(2440-2500 \mathrm{~nm})$ measurement ranges were omitted due to a low signal to noise ratio (lower than 90). The final number of wavelengths used as model input was 205. Information for these 205 wavelengths was further processed. Steps in the spectral reflectance curves were observed at the spectrometer changeovers. Most likely this effect resulted from the Petri dishes used as sample holders and their specific index of refraction.

When choosing the validation set, care was taken to assure that validation samples were representative of the whole study area. Thus, samples were systematically chosen by selecting from every land use system and under the different (slope and aspect) sampling units. These samples, which constituted $31 \%$ of the total samples, were selected for chemical analysis, which was used to validate SOC model prediction.

Regarding the chemical method, the elemental CNS analyser (vario MICRO tube, Elementar) was used for SOC estimates. For SOC measurement, $1 \mathrm{~g}$ of soil is pre-treated with 10 drips of $\mathrm{H} 3 \mathrm{PO} 4$ in order to remove carbonate. The sample is combusted at $1150{ }^{\circ} \mathrm{C}$ with constant helium flow, carrying pure oxygen to ensure complete oxidation of organic materials. The $\mathrm{CO}_{2}$ gas is produced and detected by a thermal conductivity detector.

A calibration and validation with partial least square regression were used based on cross-validation ("leave one out") in order to ensure simultaneous reduction/correlation of both the spectral information and the concentration data obtained from the chemical analysis.

After prediction of the remaining SOC sample values, a set of statistical parameters was applied in order to assess the accuracy of results such as the coefficient of determination $\left(R^{2}\right)$, which measures the extent to which a regression line estimates real data points; the residual prediction deviation (RPD), which evaluates the quality of a validation; and the root mean square error of the prediction (RMSEP), which assesses the accuracy of the model. These parameters evaluate the performance quality of the soil spectroscopy model (Viscarra Rossel et al., 2006).

\subsubsection{Statistical analysis}

Regarding the soil spectral library analysis, a partial least squares regression (PLS regression) was used in RStudio to validate the spectral prediction model while assessing the coefficient of determination $\left(R^{2}\right)$, residual prediction deviation (RPD), and root mean square error of the prediction (RMSEP).

After generating the soil spectral library, a test of normality based on Sullivan and Verhoosel (2013) was carried out in order to check the normality distribution of the data.

The Statistical Package for the Social Sciences (SPSS 20.0) software was used in order to compare the averages 


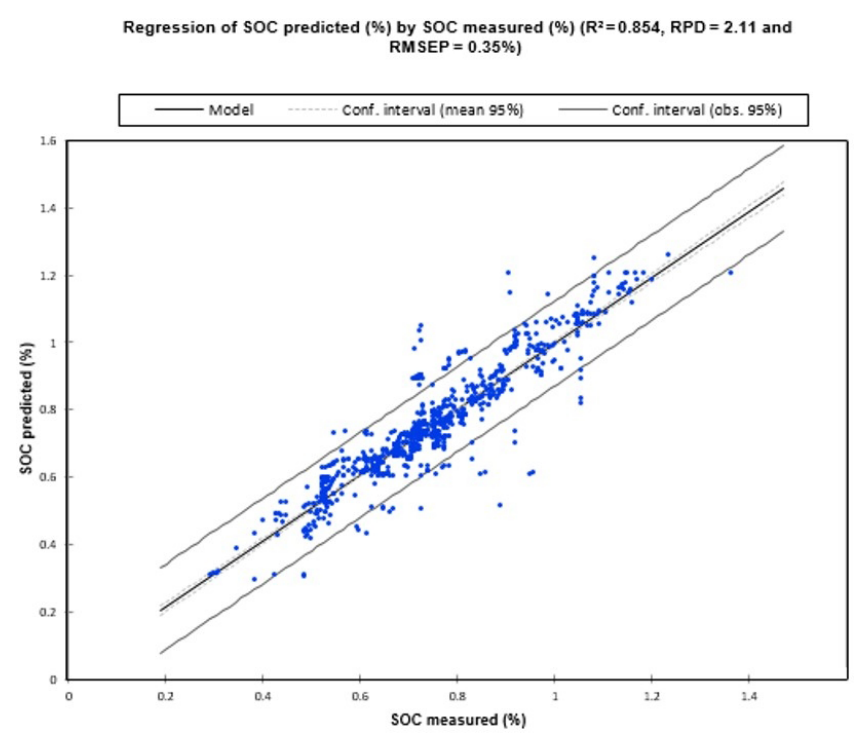

Figure 3. SOC values from chemical analysis plotted against SOC prediction.

obtained under the different factors. Variance analyses and multiple comparisons (MANOVA test) were carried out to determine the effect of the different factors (land use, slope, and aspect) on the variation of the SOC. Results were significant when $p<0.05$. The interaction effect between the factors was tested using the technique of split file. The results were grouped according to the land use factor and the effect of the slope and aspect were tested for each land use value.

Results were presented in histograms using Excel XLSTAT. We then assessed the variation of SOC under the different selected factors.

\section{Results}

\subsection{Soil spectral library as an integrative indicator of soil quality}

SOC content was plotted against SOC content predictions as displayed in Fig. 3.

The obtained spectral prediction model has $R^{2}=0.85$, $\mathrm{RPD}=2.11$, and $\mathrm{RMSEP}=0.35 \%$, which was rated excellent for prediction because RPD $>2$ (Viscarra Rossel et al., 2006). This means that the model is able to determine accurately the SOC content of $85 \%$ of the samples. The RPD $(2.11>2)$ also showed that the model developed is of good quality and can be used to predict the remaining spectra and for further development of the spectral library.

Regarding the normality of the data, the test showed a high correlation of 0.95 between the overall data and their corresponding $z$ scores. Therefore, this means that the data are approximately normally distributed.
Table 4. MANOVA results showing the significance of the impact of land use, slope, and aspect for SOC $(n=1440)$.

\begin{tabular}{lrr}
\hline & $F$ & Sig. \\
\hline LUS & 395.263 & $\mathbf{0 . 0 0 0}$ \\
slope & 76.505 & $\mathbf{0 . 0 0 0}$ \\
aspect & 11.093 & $\mathbf{0 . 0 0 1}$ \\
\hline \multicolumn{2}{l}{ Sig. $<0.05$ (statistically significant } \\
difference) in bold. Sig. $>0.05$ (no \\
statistically significant difference).
\end{tabular}

Table 5. MANOVA results regarding significance of all the variables under different LUS.

\begin{tabular}{llrr}
\hline LUS & Variables & $F$ & Sig. \\
\hline Forests & slope & 1.806 & 0.176 \\
& aspect & 2.931 & 0.094 \\
\hline Field crops & slope & 51.429 & $\mathbf{0 . 0 0 0}$ \\
& aspect & 1.028 & 0.312 \\
\hline Permanent crops & slope & 36.474 & $\mathbf{0 . 0 0 0}$ \\
& aspect & 0.068 & 0.795 \\
\hline \multirow{2}{*}{ Grazing lands } & slope & 8.242 & $\mathbf{0 . 0 0 1}$ \\
& aspect & 5.971 & $\mathbf{0 . 0 1 7}$ \\
\hline
\end{tabular}

Sig. $<0.05$ (statistically significant difference) in bold. Sig. $>0.05$ (no statistically significant difference).

\subsection{Significance effects of all the variables}

A multivariate MANOVA analysis revealed the variables that had statistically significant differences in SOC related to land use systems, slopes, and aspects. Table 4 shows the results of the significance analysis for each of the three variables. The highest significance was reported for land use, followed by slope and aspect.

The analysis of the significance of the different variables for each land use type is presented in Table 5.

For forest land use, no variables were significant, indicating that the variation of the SOC with high contents in those components was not related to slope or aspect. For field crops and permanent crops, only slope had a significant effect on SOC. For grazing lands, both variables (slope and aspect) revealed significant effects on SOC content.

\subsection{SOC according to land use systems}

SOC content for different land use systems is shown in Fig. 4. The forest LUS had the highest SOC content, with $1.09 \%$. Permanent crops had the second highest values, with $0.87 \%$ SOC content. The lowest SOC content was found for field crops $(0.70 \%)$ and grazing soils $(0.74 \%)$. 


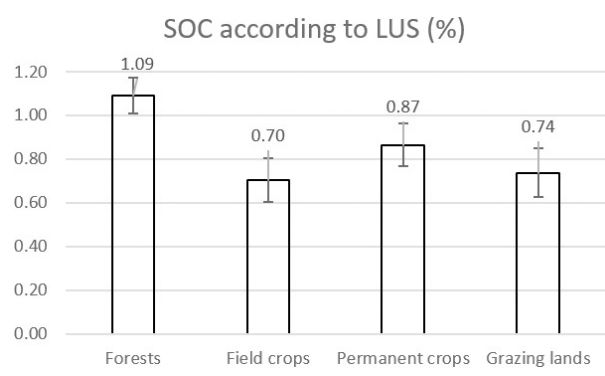

Figure 4. SOC contents according to land use systems in the Wadi Beja watershed, Tunisia.

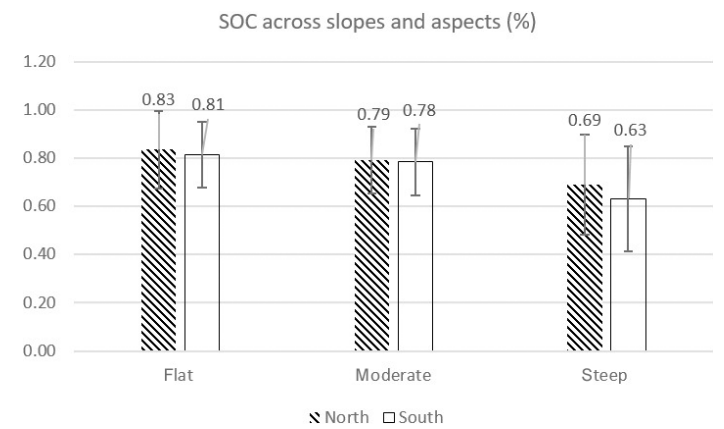

Figure 5. SOC rates according to slope and aspect in the Wadi Beja watershed, Tunisia.

According to the MANOVA results, land use systems significantly affect SOC content. In the study area, the lowest SOC content was found in field cropping soils $(0.70 \%)$ and the highest SOC content in the forests $(1.09 \%)$.

\subsection{Impact of slope and aspect on SOC}

Figure 5 shows the highest SOC content $(0.81 \%-0.83 \%)$ on flat slopes and slightly reduced SOC on moderate slopes $(0.98 \%-0.79 \%)$. Both flat and moderate slopes revealed no significant difference between north-facing and south-facing slopes (difference $<0.02 \%$ ). The lowest SOC was on steep south-facing slopes with $0.63 \%$, followed by steep northfacing slopes with $0.69 \%$ SOC.

\subsection{Impact of land use, slope, and aspect on SOC}

When evaluating the impact of slopes on SOC variations under the different LUS, the results presented in Fig. 6 reveal that in forest plantations, the highest SOC content was observed in flat and north-facing areas $(1.15 \%)$. On moderate slopes in north-facing areas, $1.14 \%$ SOC was found and $1.09 \%$ SOC in steep north-facing areas. As previously shown, statistically, the slope has no significant effect on SOC variation under the forest LUS.

For field crops, the highest SOC content was found in flat north-facing areas $(0.75 \%)$, followed by $0.69 \%$ on moderate slopes in north-facing areas and then very low figures of

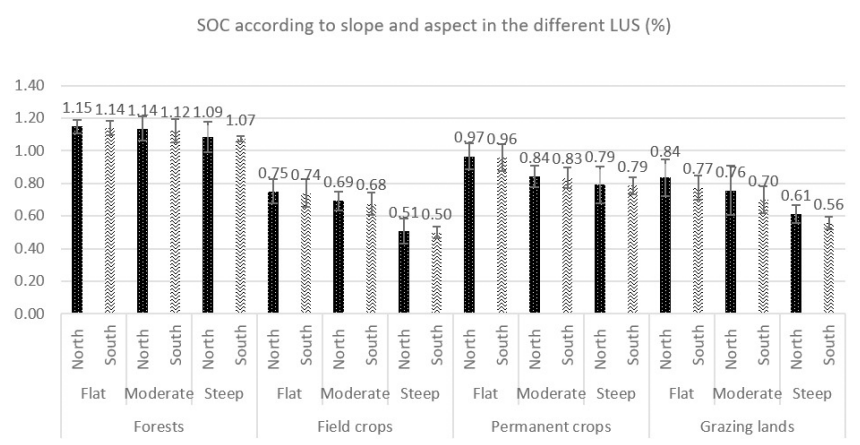

Figure 6. SOC contents according to slope and aspect for the different land use systems.

$0.51 \%$ on steep slopes in north-facing areas. Figure 6 clearly shows a marked decline in SOC with increased slopes under field crops. For permanent crops, the decrease with increasing slopes is less than that of the field crops. The highest SOC content was found in north-facing areas, first on flat slopes $(0.97 \%)$, second on moderate slopes $(0.84 \%)$, and third on steep slopes $(0.79 \%)$. Finally, on grazing lands, the different slopes showed marked differences. In flat north-facing areas, SOC was $0.84 \%$, while it was $0.77 \%$ in flat south-facing areas; in moderate north-facing areas it was $0.76 \%$ and in moderate south-facing areas $0.70 \%$; and in steep north-facing areas it was $0.61 \%$, while it was $0.56 \%$ in steep south-facing areas.

The MANOVA test showed that aspect has no significant effect on SOC variation for forests, field crops, or permanent crops. Only for grazing land does aspect have a significant effect on SOC variation, with north-facing soils having greater SOC content than south-facing areas. See Fig. 6 and Table 5.

\section{Discussion}

The Mediterranean region is generally characterized by poor soils with low SOC content (around $2 \%$ ) due to their nature and to being overused by agriculture, which means that they have low carbon inputs from plant residues and low canopied density, and are subjected to inappropriate management practices (Verheye and De la Rosa, 2005; Cerdà et al., 2016).

Land management is shown to be a key indicator affecting SOC distribution, influencing topsoil in particular (Ferreira et al., 2012). In Mediterranean areas in particular, land management is a significant factor given the limitations in SOC accumulation. Moreover, high SOC reflects undisturbed soil and high soil quality, as is the case in forest land use (CorralFernández et al., 2013).

Regarding the soil spectral library, the obtained spectral responses were well correlated, which means that the prediction model is excellent. Some outliers were detected, and their corresponding soil samples were assessed to check the reasons for their reflectance. This differences can be explained by the fact that some spectral responses were influ- 
enced by the colour of the soils. Wolfgramm (2007) found that the spectral responses of dark soils give over-predicted values and those of light soils give under-predicted values. In this case, if samples are identified as outliers, the existing spectral library needs to be extended to include all the variable soils. Thus additional reference values from soil chemical analysis have to be obtained and calibration models for an extended reference sample set need to be developed.

The study by Hassine et al. (2008) concluded that SOC content does not exceed $2 \%$ in north-western Tunisia; our prediction model falls within this amount with a maximum organic carbon percentage of $1.2 \%$. This state of low SOC in soils used for agriculture, compared to forests - which have little indication of soil degradation - has been confirmed by various authors (Arrouays et al., 1994; Cerri, 1988; Robert, 2002). This low content has negative impacts on the soil structure, which is built mainly by means of mineral colloids; its stability is affected, leading to numerous deficiencies in production and susceptibility to degradation factors. Cereal soils may have acquired a balance between SOC inputs and losses, but at a very low equilibrium level compared to forests, with the latter having less decline in SOC and being protected against erosion, which is the main type of land degradation in the study area (Hassine et al., 2008).

Previous studies have shown that SOC can play a significant role in monitoring soil quality related to land use and reduction of soil degradation (Shukla et al., 2006; Hassine et al., 2008). The soil spectral library made it feasible to gain some interpretations and therefore to generate some recommendations for land use planners regarding assessing SOC variability, as an integrative soil quality measure.

The results for the impact of land use on SOC indicate that field crops have the lowest SOC content. This could be the result of land degradation due to inappropriate agricultural management such as intensive tillage, the removal of crop residues, reduced vegetation cover, deteriorated soil aggregation and erosion, and a continuous monoculture system. This finding is coherent with the results of several researchers (Lemenih and Itanna, 2004; Lal, 2005; MuñozRojas et al., 2015; Hamza and Anderson, 2005), who have revealed a significant decline in SOC content in cropland compared to natural forests. Herrick and Wander (1997) found that in annual cropping systems, the distribution of SOC is highly influenced by land management practices such as reduced tillage, rotation, fertilization, and shifting cultivation. Consistent with the study by Hassine et al. (2008) in northwestern Tunisia, the reduced OM decomposition rates are a result of intensive agricultural practices: monoculture, tillage on steep slopes, and tillage in wet seasons, in addition to other topographic features, which may lead to a decrease in SOC.

Changing annual field crops by inter-planting them with permanent tree crops has increased the SOC of soils under previous annual field crops almost halfway to the level of SOC in forests $(0.87 \%)$. Intercropping previously mono-cropped fields with tree crops (olive, almond, and pomegranate trees) between 1982 and 1985 significantly increased SOC within 30-35 years. Creating agroforestry systems in this way is considered to have been an appropriate land management intervention in north-western Tunisia. However, some farmers made no changes to their land management, as they did not perceive the advantages of the agroforestry system (Jendoubi and Khemiri, 2018). Yet agroforestry systems are globally recognized, since they are more efficient at capturing and utilizing resources than grassland systems or single-species cropping (Nair et al., 2011).

Grazing lands, even though they are not tilled, have a low content of SOC $(0.74 \%)$, only slightly higher than annual crops (Fig. 3). Continued overgrazing and reduction of vegetation cover seem to degrade the soils and their SOC. A low SOC content can persist due to a lack of appropriate grassland management. Open pasture without canopies and weak grass-vegetation cover increase the vulnerability of this land use system to soil degradation and SOC decline. Various studies have shown that the way grazing land is managed affects SOC (Wu et al., 2003; Soussana et al., 2004): overused grazing lands with less vegetation cover are more affected by soil erosion and soil exposure to wind and rain, leading to greater SOC loss. Notably, grassland management strongly affects SOC content, which decreases as grazing intensities increase (Neff et al., 2005).

The highest SOC content was found in the forests. The explanation for this is that forest has dense cover, which protects soil from being exposed to any other factors such as erosion; hence, the SOC content is less affected. This finding has been confirmed by many authors, who have shown that in Mediterranean areas, many forest soils are rich in OM; as a consequence, these soils supply a large input of carbon and have a low litter decomposition, which means that they are distinguished by high SOC (Lal, 2005; FAO, 2010), which is highly related to the lower amount of natural and humaninduced disturbance in the forests.

Regarding the impact of slope on SOC variation, our results show that the higher the slope, the lower the SOC content. Irvin (1996) specified that generally, with increasing slope, OM lixiviation is reduced, mineral is weathered, clay is translocated, and horizons are differentiated.

Moreover, topography has a significant impact on soil temperature, soil erosion, runoff, drainage, and soil depth - and hence soil formation. The high SOC variation on hillslopes is explained by the decomposition rates of OM and litter input differences (Yimer et al., 2006).

When assessing the results of the impact of aspects on SOC variation, south-facing terrain has lower SOC content than north-facing terrain, which is explained by its exposure to the highest solar radiation and, in particular, the highest temperature during the vegetation period and the long hot summers. This implies high evaporation and a high burndown of OM due to high temperature, less moisture in soils, and consequently a slowdown of the decomposition of OM. 
In addition, according to our findings, the impact of both slope and aspect on SOC content was very distinct, as indicated statistically by a significant effect on SOC content in the MANOVA. The issue is that steep and south-facing slopes are more sensitive to degradation than other areas, which is explained by the fact that steepness increases runoff and soil erosion and southern exposure increases evapotranspiration and temperatures, thus decreasing the availability of nutrients, water, and SOC to plants. Apart from differences in land use management, SOC variation is mainly affected by environmental factors in soil along with topographic features (slope and aspect).

The literature links temperature and moisture to OM decomposition in soils (García Ruiz et al., 2012; Griffiths et al., 2009; Perry, 1994). As shown by Garcia-Pausas et al. (2007), in the Mediterranean area, shaded areas such as north-facing or colder southern areas regularly sustain high moisture content for longer and consequently become more fertile and productive, in contrast to south-facing areas, which are exposed to high radiation and thus occasional water deficits.

With regard to steepness and aspect, the higher the slope, the more exposed to the south, and the more affected by erosion and different climatic conditions, the lower the SOC content (Yimer et al., 2007, 2006). Different topographic features are considered to have different microclimatic and vegetation community types and thus significant variations in SOC. Topography (slope and aspect) hence plays a crucial role in relation to temperature and moisture regimes. The temperature is highly influenced by solar radiation, which has a role in soil chemical and biological processes and vegetation distribution (Bale et al., 1998). Hence, the temperature of the soil plays a key role in monitoring the biomass decomposition rate and thus affects the SOC distribution, by either delaying or accelerating its decomposition (Scowcroft et al., 2008).

From the results of assessing the impact of slope combined with land use, we can see that the highest SOC content was observed in flat areas under all land use systems, and it tended to decrease in steep areas. In general, under all land use systems, we can observe the same tendency for SOC variation, with the highest SOC content in flat positions and the lowest in steep positions.

This can be explained by minimal erosion in flatter areas and higher deposition of sediments, resulting in accumulation of SOC. Erosion causes stripping of the soil in hillslope areas. As shown by Yoo et al. (2006), the prevalent portion of SOC is deposited in depositional areas, with hillslopes being more susceptible to sporadic mass wasting events, continuous soil erosion and production, and consequently less SOC storage. In addition, the highest erodibility is related to hilly areas where soils have a tendency to be shallow, coarse in texture, and low in OM, while lower erodibility is observed in flat areas with organic-rich, deep, and leached soils (Lawrence, 1992).
From the clear difference in the variation in SOC under forest and field crop land use systems, we interpret that it is the land use factor that dominates SOC distribution rather than the slope factor.

In general, steep slopes have a lower SOC content than flat land, as they are more vulnerable to erosion, especially when associated with inappropriate management and overuse (Reza et al., 2016; Bouraima et al., 2016). Cropland in sloping areas is highly vulnerable to water erosion, which leads to extensive soil disturbance, while land use patterns affect vegetation cover, soil physical properties such as SOC, and surface litter. Therefore, this provokes the runoff and soil erosion processes that accompany nutrient loss (Dagnew et al., 2017; Montenegro et al., 2013). Therefore, the extent of nutrient loss differs according to land use systems, as is the case with cereal monoculture in the study site.

Hence, in order to improve and maintain soil quality parameters for sustainable productivity, it is crucial to reduce intensive cultivation and integrate the use of inorganic and organic fertilizers.

In agricultural areas, continuous intensive cultivation without appropriate soil management practices has contributed to loss of SOC. Kravchenko and Bullock (2002) and Jiang and Thelen (2004) found that within variability in topography, slope was considered to be a major crop yield limiting factor.

Correspondingly, after inter-planting permanent crops with field crops, SOC content was enhanced. Herrick and Wander (1997) showed that after introducing permanent crops, slope significantly affected SOC content.

Our results also show less SOC in south-facing areas and confirm findings from other studies on the interaction effects of slope and aspect on OM decomposition (Griffiths et al., 2009).

According to McCune and Keon (2002), the reason for these results is that slope and aspect play a significant role in solar radiation redistribution, hence the solar radiation heterogeneity on hillslopes leading to differences in soil moisture and temperature. Huang et al. (2015) stated that the SOC content in shaded aspect areas was significantly higher than in sunny aspect areas. Therefore, increases in SOC and OM accumulation are supported by increased moisture and reduced temperature, while decreased soil temperature usually results in decreased OM decomposition rates and litter decay rates (Blankinship et al., 2011).

For grazing lands, all the variables (slope and aspect) revealed significant effects on SOC content, as was also shown in the study of Bird et al. (2001). SOC content is generally low, though it is higher in flat areas. This is explained by overgrazing and pressure on the different topographic features, as they are all easily accessible to livestock. Even on steep slopes there is pressure and overgrazing, in addition to the exposure of these areas to erosion by wind and rain. This highlights the susceptibility of this land use system to erosion and deterioration of soil quality. 
The reason why grazing land use systems are the most sensitive to all the tested variables (slope and aspect) can be explained as follows: in the study area, grazing land was generally open grassland, and it is evident that soils are more sensitive in open grassland than under tree canopies, as SOC stocks under tree canopies are in general higher than in open grassland (e.g. Seddaiu et al., 2013). Moreno et al. (2007) also found that the SOC content in the topsoil beneath the tree canopies was "around twice as high as beyond the tree canopy". This can also be related to overgrazing, as shown in a literature review of the effects of overgrazing in the Mediterranean basin (Sanjari et al., 2008; Costa et al., 2012). Furthermore, the semi-arid climate and inclined topography prevailing in Mediterranean grazing lands render ecosystems vulnerable to SOC losses. As shown by Ryan et al. (2008), the higher the level of grazing, or the greater the residue removal, the greater the decline in mean SOC level. The reason behind the decrease in carbon and nutrient cycling is mainly that SOC in grassland is accumulated in roots, which leads to its loss with every removal of aboveground biomass.

The most likely clarification for the results obtained on decreased SOC content in steep south-facing areas under the field crops land use system is that soils are affected by soil degradation initiated by inappropriate land management and consequently have weak vegetation cover. This condition makes these soils more sensitive to the south-facing exposition characterized by higher solar radiation and evaporation, and thus decreases soil moisture and biological activity, resulting in SOC loss. Wakene and Heluf (2004) have also indicated that intensive cultivation aggravates $\mathrm{OM}$ oxidation and hence reduces SOC content.

Therefore, some options for sustainable land management practices can be recommended, such as establishment of enclosures (Mekuria and Aynekulu, 2013), which could be efficient in recovering the degraded grazing land areas of the watershed. In addition to protecting trees against damage caused by uncontrolled grazing animals by installing fences and trunk protection, mixing of animal species, mostly sheep and goats but also cows and horses, and setting additional fodder provision could be a feature of the summer season.

In order to maintain improved soil quality and sustainable productivity in croplands, there is a need to reduce intensive cultivation, agroforestry, and practice of fallow, integrate use of inorganic and organic fertilizers, and pay more attention to the most vulnerable areas (steep and south-facing areas).

There are strong indications that agroforestry has been successful in retaining and even improving SOC and soil fertility: the results show that introducing an agroforestry system - e.g. combining an olive plantation with annual field crops - has increased SOC content in the most vulnerable areas. Thus, such types of sustainable land use should be the focus of land managers and land use planners.

\section{Conclusions}

Land management can profoundly affect SOC stocks. Application of soil and water conservation measures is crucial for sustaining agricultural fields and preventing or reducing soil degradation.

In areas with exceedingly erodible soils, such as those on steep slopes and south-facing zones as shown in this study, greater efforts to reduce SOC decline are required on steep slopes and south-facing land than in flat areas and northfacing land. However, a further study of the area is recommended, especially land use in combination with other topographic features such as altitude and curvature and their effects on SOC content.

By far the best option, however, is to identify land management practices that increase $\mathrm{C}$ stocks whilst at the same time enhancing other aspects of the environment, e.g. improved soil fertility, decreased erosion, greater profitability, or improved yield of agricultural and forestry products. There are a number of management practices available that could be implemented to protect and enhance existing $\mathrm{C}$ sinks now and in the future.

Since such practices are consistent with, and may even be encouraged by, many current international agreements and conventions, their rapid adoption should be as widely encouraged as possible.

Finally, this paper contributes towards filling a gap in investigations into the impacts of various land uses on SOC in Tunisia. The results presented in this paper are valid for calibration of further soil spectral libraries in north-western Tunisia; this was the first soil spectral library collated in the country and the methodology can be replicated and applied to other areas. Further studies on SOC variation depending on land use and topographic features are needed to inform sustainable land management in Tunisia.

Data availability. The data that support the findings of this study are available by request from the corresponding author (Donia Jendoubi). The soil spectral library is managed by the Ministry of Agriculture of Tunisia.

Author contributions. The sampling design was done by DJ and HL. HL contributed and assisted DJ during the field work. The lab analysis procedure, the spectroscopy measurements, and the statistics were carried out by DJ. DJ prepared the manuscript with valuable contributions of the two co-authors CIS and HL and undertook the revisions during the review process. CIS provided the lab facilities and supervised with the assistance of HL and DJ during her PhD studies.

Competing interests. The authors declare that they have no conflict of interest. 
Acknowledgements. The authors thank Tina Hirschbuehl, Dee Cooke, and William Critchley for English proofreading. Donia Jendoubi would like to thank the head of the Department of Geography, University of Zurich (UZH), for lending her the spectrometer and allowing her to travel with and use it in her field work.

Financial support. This research has been supported by the Islamic Development Bank (grant no. 78/TUN/P34) and the Swiss Federal Commission for Scholarships for Foreign Students (grant no. 2014.0968/Tunesien/OP).

Review statement. This paper was edited by Estela Nadal Romero and reviewed by two anonymous referees.

\section{References}

Achiba, W. B., Gabteni, N., Lakhdar, A., Laing, G. D., Verloo, M., Jedidi, N., and Gallali, T.: Effects of 5-year application of municipal solid waste compost on the distribution and mobility of heavy metals in a Tunisian calcareous soil, Agr. Ecosyst. Environ., 130, 156-163, 2009.

Álvaro-Fuentes, J., López, M., Cantero-Martínez, C., and Arrúe, J.: Tillage effects on soil organic carbon fractions in Mediterranean dryland agroecosystems, Soil Sci. Soc. Am. J., 72, 541547,2008

Amare, T., Hergarten, C., Hurni, H., Wolfgramm, B., Yitaferu, B., and Selassie, Y. G.: Prediction of soil organic carbon for Ethiopian highlands using soil spectroscopy, ISRN Soil Science, 2013, 720589, https://doi.org/10.1155/2013/720589, 2013.

Arrouays, D., Kicin, J., Pélissier, P., and Vion, I.: Evolution des stocks de carbone des sols après déforestation: analyse spatiotemporelle à l'échelle d'un paysage pédologique, Étude et gestion des sols, 1, 7-15, 1994.

AVFA (Agence de la Vulgarisation et de la Formation Agricoles): Informations Régionales $>$ Beja. Agricoles. Tunisie, Ministère de l'Agriculture des ressources hydrauliques et de la pêche, available at: http://www.avfa.agrinet.tn (last access: 13 March 2019), 2016

Bale, C. L., Williams, B. J., and Charley, J. L.: The impact of aspect on forest structure and floristics in some Eastern Australian sites, Forest Ecol. Manage., 110, 363-377, 1998.

Barham, P., Begg, E., Foote, S., Henderson, J., Jansen, P., Pert, H., and Woolner, D.: Guidelines for soil description. Disease management $\&$ health outcomes, vol. 1, FAO, Viale delle Terme di Caracalla, 00100 Rome, Italy, https://doi.org/10.2165/00115677199701040-00003, 1997.

Bhattacharyya, R. Ghosh, B. N., Mishra, P. K., Mandal, B., Srinivasa Rao, C. H., Sarkar, D., Das, K., Anil, K. S., Lalitha, M., Hati, K. M., and Franzluebbers, A. J.: Soil degradation in India: challenges and potential solutions, Sustainability, 7, 3528-3570, 2015.

Bird, S. B., Herrick, J. E., and Wander, M. M.: Exploiting heterogeneity of soil organic matter in rangelands: benefits for carbon sequestration, edited by: Follett, R. F., Kimble, J. M., and Lal, R., The Potential of U.S. Grazing Lands to Sequester Carbon and Mitigate the Greenhouse Effect, CRC Press, Boca Raton FL, USA, 2001.

Blankinship, J. C., Niklaus, P. A., and Hungate, B. A.: A metaanalysis of responses of soil biota to global change, Oecologia, 165, 553-565, 2011.

Bouraima, A. K., He, B., and Tian, T.: Runoff, nitrogen $(\mathrm{N})$ and phosphorus $(\mathrm{P})$ losses from purple slope cropland soil under rating fertilization in Three Gorges Region Environ. Sci. Pollut. Res. Int., 23 (5) (2016), pp. 4541-4550, 2016.

Brahim, N., Bernoux, M., Blavet, D., and Gallali, T.: Tunisian soil organic carbon stocks, International Journal of Soil Science, 5, 34-40, 2010.

Cerdà, A., González-Pelayo, Ó., Giménez-Morera, A., Jordán, A. Pereira, P,, Novara, A., Brevik, E. C., Prosdocimi, M., Mahmoodabadi, M., Keesstra, S., García Orenes, F., and Ritsema, C.: The use of barley straw residues to avoid high erosion and runoff rates on persimmon plantations in Eastern Spain under low frequency - high magnitude simulated rainfall events, Soil Res., 54, 154165, https://doi.org/10.1071/SR15092, 2016.

Cerri, C.: Dynamique de la matiere organique du sol aprés défrichement et mise em culture, Utilisation du traçage isotopique naturel em 13C, Cah. ORSTOM, 24, 335-336, 1988.

Corral-Fernández, R., Parras-Alcántara, L., and Lozano-García, B.: Stratification ratio of soil organic $\mathrm{C}, \mathrm{N}$ and $\mathrm{C}: \mathrm{N}$ in Mediterranean evergreen oak woodland with conventional and organic tillage, Agr. Ecosyst. Environ., 164, 252-259, 2013.

Costa, C., Papatheodorou, E. M., Monokrousos, N., and Stamou, G. P.: Spatial variability of soil organic C, inorganic N and extractable $\mathrm{P}$ in a Mediterranean grazed area, Land Degrad. Dev., https://doi.org/10.1002/ldr.2188, 2012.

Dagnew, D. C., Guzman, C. D., Akal, A. T., Tebebu, T. Y., Zegeye, A. D., Mekuria, W., Tilahun, S. A., and Steenhuis, T. S.: Effects of land use on catchment runoff and soil loss in the sub-humid ethiopian highlands, Ecohydrol. Hydrobiol., 17, 274-282, 2017.

Diodato, N. and Ceccarelli, M.: Multivariate indicator Kriging approach using a GIS to classify soil degradation for Mediterranean agricultural lands, Ecol. Indic., 4, 177-187, 2004.

Doran, J. W.: Soil health and global sustainability: translating science into practice, Agr. Ecosyst. Environ., 88, 119-127, 2002.

Doran, J. W. and Zeiss, M. R.: Soil health and sustainability: managing the biotic component of soil quality, Appl. Soil Ecol., 15, 3-11, 2000.

FAO: Global Forest Resources Assessment 2010, 378 pp., ISBN 978-92-5-106654-6, 2010.

Ferreira, A. O., Sá, J. C. M., Harms, M. G., Miara, S., Briedis, C., Quadros, C., Santos, J. B., Canalli, L. B. S., and Dias, C. T. S.: Stratification ratio as soil carbon sequestration indicator in macroaggregates of Oxisol under no-tillage, Cienc. Rural, 42, 645-652, 2012 (in Portuguese).

Garcia-Pausas, J., Casals, P., Camarero, L., Huguet, C., Sebastià, M.-T., Thompson, R., and Romanyà, J.: Soil organic carbon storage in mountain grasslands of the Pyrenees: effects of climate and topography, Biogeochemistry, 82, 279-289, 2007.

García Ruiz, J., Lana Renault, N., Nadal Romero, E., and Beguería, S.: Erosion in Mediterranean Ecosystems: changes and future challenges, Geophys. Res. Abstr., 14, EGU2012-5901, EGU General Assembly 2012, Vienna, Austria, 2012.

Griffiths, R. P., Madritch, M. D., and Swanson, A. K.: The effects of topography on forest soil characteristics in the Oregon Cascade 
Mountains (USA): Implications for the effects of climate change on soil properties, Forest Ecol. Manage., 257, 1-7, 2009.

Hamza, M. A. and Anderson, W. K.: Soil compaction in cropping systems - a review of the nature, causes and possible solutions, Soil Till. Res., 82, 121-145, 2005.

Hassine, H. B., Aloui, T., Gallali, T., Bouzid, T., El Amri, S., and Hassen, R.: Évaluation quantitative et rôles de la matière organique dans les sols cultivés en zones subhumides et semiarides méditerranéennes de la Tunisie, Agrosolutions, 19, 4-14, 2008.

Herrick, J. E. and Wander, M.: Relationships between soil organic carbon and soil quality in cropped and rangeland soils: the importance of distribution, composition, and soil biological activity, edited by: Lal, R., Kimble, J. M., Follett, R. F., and Stewart, B. A., Soil Processes and the Carbon Cycle, CRC Press, Boca Raton (1997), 405-425, 1997.

Hill, J. and Schütt, B.: Mapping complex patterns of erosion and stability in dry Mediterranean ecosystems, Remote Sens. Environ., 74, 557-569, 2000.

Hill, J., Stellmes, M., Udelhoven, T., Röder, A., and Sommer, S.: Mediterranean desertification and land degradation: mapping related land use change syndromes based on satellite observations, Global Planet. Change, 64, 146-157, 2008.

Huang, Y. M., Liu, D., and An, S. S.: An Effect of slope aspect on soil nitrogen and microbial properties in the Chinese Loess region, Catena, 125, 135-145, 2015.

Irvin, B. J.: Spatial Information Tools for Delineating Landform Elements to Support Soil/Landscape Analysis, PhD Thesis, University of Wisconsin-Madison, 1996.

Jendoubi, D. and Khemiri, H.: Le système d'Agroforesterie pour la protection des terres et l'amélioration des revenus des exploitants dans les zones montagneuses de Nord Ouest Tunisien, https:/qcat.wocat.net/en/wocat/technologies/ view/technologies_3722/(last access: 25 January 2019), 2018.

Jendoubi, D., Hodel, E., Liniger, H. P., and Subhatu, A. T.: Land degradation assessment using landscape unit approach and normalized difference vegetation index in Northwest of Tunisia, Journal of Mediterranean Ecology, 17, 67-79, 2019.

Jianga, P. and Thelen, K. D.: Effect of Soil and Topographic Properties on Crop Yield in a North-Central Corn-Soybean Cropping System, Agronomy Journal Abstract - SITE-SPECIFIC ANALYSIS, 96, 252-258, https://doi.org/10.2134/agronj2004.0252, 2004.

Jobbagy, E. G. and Jackson, R. B.: The vertical distribution of soil organic carbon and its relation to climate and vegetation, Ecol. Appl., 10, 423-436, 2000.

Karamesouti, M., Detsis, V., Kounalaki, A., Vasiliou, P., Salvati, L., and Kosmas, C.: Land-use and land degradation processes affecting soil resources: evidence from a traditional Mediterranean cropland (Greece), Catena, 132, 45-55, 2015.

Kosmas, C., Detsis, V., Karamesouti, M., Kounalaki, K., Vassiliou, P., and Salvati, L.: Exploring long-term impact of grazing management on land degradation in the socio-ecological system of Asteroussia Mountains, Greece, Land, 4, 541-559, 2015.

Kosmas, C., Gerontidis, S., and Marathianou, M.: The effect of land use change on soils and vegetation over various lithological formations on Lesvos (Greece), Catena, 40, 51-68, 2000.

Kravchenko, A. N. and Bullock, D. G.: Spatial variability of soybean quality data as a function of field topography: II. A Pro- posed technique for calculating the size of the area for differential soybean harvest, Crop Science, 42, 816-821, 2002.

Lal, R.: Soil quality and sustainability, in: Methods for Assessment of Soil Degradation, Advances in Soil Science, edited by: Lal, R., Blum, W. H., Valentine, C., and Stewart, B. A., CRC Press, Boca Raton, FL, 17-30, 1998.

Lal, R.: Forest soils and carbon sequestration, Forest Ecol. Manage., 220, 242-258, 2005.

Lawrence, W. M.: The variation of soil erodibility with slope position in a cultivated Canadian prairie landscape, Earth Surf. Proc. Land., 17, 543-556, 1992.

Lemenih, M. and Itanna, F.: Soil carbon stocks and turnovers in various vegetation types and arable lands along an elevation gradient in southern Ethiopia, Geoderma, 123, 177-188, 2004.

McCune, B. and Keon, D.: Equations for potential annual direct incident radiation and heat load, J. Veg. Sci., 13, 603-606, 2002.

Mekuria, W. and Aynekulu, E.: Exclosure land management for restoration of the soils in degraded communal grazing lands in northern Ethiopia, Land Degrad. Dev., 24, 528-538, 2013.

Montenegro, A. A. A., Abrantes, J. R. C. B., Lima, J. L. M. P. D., Singh, V. P., and Santos, T. E. M.: Impact of mulching on soil and water dynamics under intermittent simulated rainfall, Catena, 109, 139-149, 2013.

Moreno, G., Obrador, J. J., and García, V.: Impact of evergreen oaks on soil fertility and crop production in intercropped dehesas, Agr. Ecosyst. Environ., 119, 270-280, 2007.

Mutuo, P. K., Shepherd, K. D., Albrecht, A., and Cadisch, G.: Prediction of carbon mineralization rates from different soil physical fractions using diffuse reflectance spectroscopy, Soil Biol. Biochem., 38, 1658-1664, 2006.

Muñoz-Rojas, M., Jordán, A., Zavala, L. M., De la Rosa, D., AbdElmabod, S. K., and Anaya-Romero, M.: Organic carbon stocks in Mediterranean soil types under different land uses (Southern Spain), Solid Earth, 3, 375-386, https://doi.org/10.5194/se3-375-2012, 2012.

Muñoz-Rojas, M., Jordán, A., Zavala, L., De la Rosa, D., AbdElmabod, S., and Anaya-Romero, M.: Impact of land use and land cover changes on organic carbon stocks in Mediterranean soils (1956-2007), Land Degrad. Dev., 26, 168-179, 2015.

Nachtergaele, F., Biancalani, R., Bunning, S., and George, H.: Land degradation assessment: the LADA approach, in: 19th World Congress of Soil Science, 1 August 2010, Brisbane, Australia, 2010.

Nair, P. K. R., Nair, V. D., Kumar, B. M., and Showalter, J. M.: Carbon sequestration in agroforestry systems, Adv. Agron., 108, 237-307, 2011.

Neff, J. C., Reynolds, R. L., Belnap, J., and Lamothe, P.: Multidecadal impacts of grazing on soil physical and biogeochemical properties in southeast Utah, Ecol. Appl., 15, 87-95, 2005.

Parras-Alcántara, L., Lozano-García, B., Keesstra, S., Cerdà, A., and Brevik, E. C.: Long-term effects of soil management on ecosystem services and soil loss estimation in olive grove top soils, Sci. Total Environ., 571, 498-506, 2016.

Perry, D. A.: Forest Ecosystems, The Johns Hopkins University Press, Baltimore, 1994.

Ping, C. L., Jastrow, J. D., Jorgenson, M. T., Michaelson, G. J., and Shur, Y. L.: Permafrost soils and carbon cycling, Soil, 1, 147$171,2015$. 
Post, W. M. and Kwon, K. C.: Soil carbon sequestration and landuse change: processes and potential, Glob. Change Biol., 6, 317327, 2000.

Reza, A., Eum, J., Jung, S., Choi, Y., Owen, J. S., and Kim, B.: Export of non-point source suspended sediment, nitrogen, and phosphorus from sloping highland agricultural fields in the East Asian monsoon region, Environ. Monit. Assess., 188, p. 692, 2016.

Robert, M.: La séquestration du carbone dans le sol pour une meilleure gestion de terres, Rapport sur les ressources en sols du monde, Organisation des Nations Unies pour l'Alimentation et l'Agriculture, Rome, 76 pp., 2002.

Ryan, J., Masri, S., Ibrikci, H., Singh, M., Pala, M., and Harris, H.: Implications of cereal-based crop rotations, nitrogen fertilization, and stubble grazing on soil organic matter in a Mediterraneantype environment, Turkish J. Agric. For., 32, 289-297, 2008.

Sanjari, G., Ghadire, H., Ciesiolka, C. A. A., and Yu, B.: Comparing the effects of continuous and time-controlled grazing systems on soil characteristics in Southeast Queensland, Aust. J. Soil Res., 46, 348-358, https://doi.org/10.1071/SR07220, 2008

Sarraf, M., Larsen, B., and Owaygen, M.: Cost of Environmental Degradation - The Case of Lebanon and Tunisia, Environmental Economics series, Paper no. 97, World Bank publications, Washington, D.C., 2004.

Scarascia-Mugnozza, G., Oswald, H., Piussi, P., and Radoglou, K.: Forests of the Mediterranean region: gaps in knowledge and research needs, Forest Ecol. Manag., 132, 97-109, 2000.

Scowcroft, P., Turner, D. R., and Vitousek, P. M.: Decomposition of Metrosideros polymorpha leaf litter along elevational gradients in Hawaii, Glob. Change Biol., 6, 73-85, 2008.

Seddaiu, G., Porcu, G., Ledda, L., Roggero, P. P., Agnelli, A., and Corti, G.: Soil organic matter content and composition as influenced by soil management in a semi-arid Mediterranean agro-silvo-pastoral system, Agr. Ecosyst. Environ., 167, 1-11, https://doi.org/10.1016/j.agee.2013.01.002, 2013.

Shepherd, K. D. and Walsh, M. G.: Development of reflectance spectral libraries for characterization of soil properties, Soil Sci. Soc. Am. J., 66, 988-998, 2002.

Shiferaw, A. and Hergarten, C.: Visible near infrared (VisNIR) spectroscopy for predicting soil organic carbon in Ethiopia, Journal of Ecology and the Natural Environment, 6, 126-139, 2014.

Shukla, M., Lal, R., and Ebinger, M.: Determining soil quality indicators by factor analysis, Soil Till. Res., 87, 194-204, 2006.

Soussana, J. F., Loiseau, P., Vuichard, N., Ceschia, E., Balesdent, J., Chevallier, T., and Arrouays, D.: Carbon cycling and sequestration opportunities in temperate grasslands, Soil Use Manage., 20, 219-230, 2004.

Stanners, D. and Bourdeau, P.: Europe's environment: the Dobris assessment Europe's environment: the Dobrís assessment: Office for Official Publication of the European Communities, 1995.
Sullivan, M. and Verhoosel, J. C.: Statistics: Informed decisions using data, New York, Pearson, 2013.

Van-Camp, L., Bujarrabal, B., Gentile, A.-R., Jones, R. J. A., Montanarella, L., Olazabal, C., and Selvaradjou, S.-K.: Reports of the Technical Working Groups Established under the Thematic Strategy for Soil Protection, EUR 21319 EN/3, Office for Official Publications of the European Communities, Luxembourg, 872 pp. 2004.

Verheye, W. and De la Rosa, D.: Mediterranean soils, in Land Use and Land Cover, from Encyclopedia of Life Support Systems (EOLSS), Developed under the Auspices of the UNESCO, EOLSS Publishers, Oxford, UK, 2005.

Viscarra Rossel, R. A., Walvoort, D. J. J., McBratney, A. B., Janik, L. J., and Skjemstad, J. O.: Visible, Near Infrared, Mid Infrared or Combined Diffuse Reflectance Spectroscopy for Simultaneous Assessment of Various Soil Properties, Geoderma, 131, 5975, https://doi.org/10.1016/j.geoderma.2005.03.007, 2006.

Wakene, N. and Heluf, G.: The impact of different land use systems on soil quality of western Ethiopia Alfisols, International Research on Food Security: Natural Resource Management and Rural Poverty Reduction through Research for Development and Transformation, Deutcher Tropentage, 5-7 October 2004, Berlin, 1-7, available at: http://www.Tropentage.de/2004/abstracts/full/ 265.pdf (last access: 15 July 2018), 2004.

Wolfgramm, B.: Land use, soil degradation and soil conservation in the loess hills of central Tajikistan, PhD thesis, Bern Universitz, Switzerland, 2007.

Wolfgramm, B., Seiler, B., Kneubühler, M., and Liniger, H.: Spatial assessment of erosion and its impact on soil fertility in the Tajik foothills, EARSeL eProceedings, 6, 12-25, 2007.

Wu, H., Guo, A., and Peng, C.: Land use induced changes in organic carbon storage in soils of China, Glob. Change Biol., 9, 305-315, 2003.

Yimer, F., Ledin, S., and Abdelkadir, A.: Soil organic carbon and total nitrogen stocks as affected by topographic aspect and vegetation in the Bale Mountains, Ethiopia, Geoderma, 135, 335-344, 2006.

Yimer, F., Ledin, S., and Abdelkadir, V.: Changes in soil organic carbon and total nitrogen contents in three adjacent land use types in the Bale Mountains, south-eastern highlands of Ethiopia, Forest Ecol. Manage., 242, 337-342, 2007.

Yoo, K., Amundson, R., Heimsath, A. M., and Dietrich, W. E.: Spatial patterns of soil organic carbon on hillslopes: integrating geomorphic processes and the biological C cycle, Geoderma, 130, 47-65, 2006. 